\title{
Possible role of changes in post-natal gonadotrophin concentrations on permanent impairment of the reproductive system in neonatally oestrogenized male rats
}

\author{
C. Bellido, L. Pinilla, R. Aguilar, F. Gaytan* and E. Aguilar \\ Department of Physiology and *Biology Section, School of Medicine, University of Córdoba, \\ 14004 Córdoba, Spain
}

\begin{abstract}
Summary. Rats were treated neonatally with oestrogen $(500 \mu \mathrm{g}$ oestradiol benzoate injected on Day 1 of life). Treatment with FSH and LH $(80 \mu \mathrm{g} / 100 \mathrm{~g}$ body wt and $40 \mu \mathrm{g} / 100 \mathrm{~g}$ body wt respectively) during the early post-natal period (Days 1-10) abolished the effects of oestradiol on the morphological and functional development of the testes and on the regulation of prolactin secretion, but had no action on the effects of oestradiol on the development of the sex accessory glands. Treatment with prolactin $(100 \mu \mathrm{g} / 100 \mathrm{~g}$ body $\mathrm{wt})$ during the early post-natal period did not affect the integrity of the reproductive system in adult life. These results suggest that neonatal oestradiol acts indirectly, through an inhibition of gonadotrophin secretion on testicular development, and directly on the development of the sex accessory glands.
\end{abstract}

Keywords: neonate; oestrogen; gonadotrophins; testis; sex accessory glands; rat

\section{Introduction}

Administration of oestrogen to neonatal male rats produces permanent changes in the development of the reproductive system. Adult animals show atrophy of the testes and sex accessory glands (Kincl et al., 1965; Aguilar et al., 1984), as well as an impaired maturation of germ (Dhar \& Setty, 1976; Gaytan et al., 1986a), Sertoli and Leydig (Gaytán \& Aguilar, 1986; Gaytán et al., 1986b) cells. These animals have decreased serum testosterone concentrations (Frick et al., 1969; Pinilla et al., 1989), increased serum prolactin values (Vaticon et al., 1985) and alterations in the LH control mechanisms with a decreased response to castration (Aguilar et al., 1984) and an increased response to LHRH administration (Pinilla et al., 1985). At the present time, there are controversial reports as to the effects of oestrogens on the hypothalamic-pituitary-testicular axis; some authors have suggested a direct action of oestrogen on the testis (Steinberger et al., 1977), while others have suggested that the effects on the testis are mainly due to the decrease in gonadotrophin secretion (van Beurden et al., 1978; Gaytán et al., 1986b).

The aim of the present study was to analyse whether the effects of oestrogen administration to neonatal male rats are due to the previously described decrease in serum gonadotrophin concentrations and/or to the increase in serum prolactin values (Aguilar et al., 1987) during the early post-natal period.

\section{Materials and Methods}

Wistar male rats were raised in our laboratory under controlled light ( $12 \mathrm{~h}$ light:12 h darkness; lights on at 07:00 h) and temperature $\left(20 \pm 2^{\circ} \mathrm{C}\right)$. The day on which litters were obtained was designated as Day 1 of life. On this day, the litter size was adjusted to 8 male rats. 
Experiment 1. On Day 1, male young were injected s.c. with $500 \mu \mathrm{g}$ oestradiol benzoate (Sigma Chemical Co, St Louis, MO, USA) (oestrogen-treated rats) or olive oil (control animals). Control and oestrogen-treated animals were submitted to a combined treatment of FSH (NIADDK oFSH-16), $80 \mu \mathrm{g} / 100 \mathrm{~g}$ body weight, and LH (USDA bLH-B-5), $40 \mu \mathrm{g} / \mathrm{l} 00 \mathrm{~g}$ body weight, or vehicle $(0.5 \% \mathrm{BSA}$ in $0.9 \% \mathrm{NaCl})$, subcutaneously, once a day from Day 1 to Day 10 .

Experiment 2. Animals were treated from Day 1 to Day 10 with prolactin (NIADDK oPrl-18), $100 \mu \mathrm{g} / 100 \mathrm{~g}$ body weight, or vehicle $\left(0.15 \mathrm{M}-\mathrm{NaCl}, 0.03 \mathrm{M}-\mathrm{NaCO}_{3} \mathrm{H}, 0.1 \% \mathrm{BSA}, \mathrm{pH} 9\right)$, subcutaneously, twice a day. All animals were killed by decapitation at 90 days of age between 10:00 and 11:00 h. The weights of the animals, testes, epididymides, seminal vesicles, ventral prostate and pituitary glands were recorded. Trunk blood was coliected, and the serum was separated by centrifugation and stored at $-20^{\circ} \mathrm{C}$ until assayed. Pituitaries were homogenized in $1 \mathrm{ml} \mathrm{NaCl}, 0.9 \%$ containing urea $(2.5 \mathrm{~mol} / 1)$, and submitted to ultrasonic treatment (Haggi \& Aoki, 1981). The samples were centrifuged for $10 \mathrm{~min}$ at $2800 \mathrm{~g}$ and the supernatants frozen at $-20^{\circ} \mathrm{C}$ until analysed for hormonal content.

Assays. Serum and pituitary concentrations of LH, FSH and prolactin were determined by a doubleradioimmunoassay method using Kits supplied by the NIADDK (Bethesda, MD, USA). Rat LH-I-6, rFSH-I-6 and rPrl-I-5 were labelled with ${ }^{125}$ I by the chloramine T method (Greenwood et al., 1963). The LH, FSH and prolactin concentrations are expressed in terms of the rLH-RP-2, rFSH-RP-2 and rPrl-RP-3 standards. Testosterone was determined by the radioimmunoassay method as described by Gay \& Kerlan (1978) with minor modifications (Rodríguez-Padilla et al., 1987), using the antiserum generously supplied by Dr G. D. Niswender (Colorado State University, Fort Collins, CO, USA). All samples were measured in duplicate in the same assay, the intraassay variations being $6 \%, 7 \%, 9 \%$ and $5 \%$ for $\mathrm{LH}, \mathrm{FSH}$, prolactin and testosterone respectively. The sensitivities were $7 \cdot 5,20$, 10 and $2.5 \mathrm{pg}$ for $\mathrm{LH}, \mathrm{FSH}$, prolactin and testosterone respectively.

Histological study. The testes and ventral prostate glands were fixed in Bouin-Hollande's fluid for $48 \mathrm{~h}$ and embedded in paraffin wax after dehydration. Sections ( $5 \mu \mathrm{m}$ thick) were stained with haematoxylin and eosin and studied under light microscopy.

Statistical analysis. Data are expressed as mean \pm s.e.m. Statistical analyses were carried out by the Student's $t$ test or the one-way analysis of variance (ANOVA) and Tukey's multiple comparison method for comparison among means. Differences were considered significant at the 0.05 level.

\section{Results}

No significant differences were found for the body weight in the different groups (data not shown). Control rats treated with FSH and LH showed increased testicular and epididymal weights with respect to the vehicle-injected rats. Oestrogen-treated rats showed a decrease in the weight of these organs and this effect was abolished by gonadotrophin administration (Table 1). On the other hand, gonadotrophin treatment did not change the weights of the ventral prostate and seminal vesicles in control rats, and the decrease in the weight of these glands induced by oestrogen was not abolished (Table 1). Oestrogen-treated rats showed decreased concentrations of testosterone, which were normalized after gonadotrophin treatment. No differences were found for the serum concentration of LH in the different groups. Gonadotrophin treatment decreased the serum concentrations of FSH both in control and oestrogen-treated rats. The increase in serum concentrations of prolactin induced by neonatal oestrogen treatment was abolished by gonadotrophin treatment, whereas no effects were found in control rats (Table 1). No differences in the pituitary content of LH, FSH or prolactin existed among the different groups (data not shown).

The post-natal administration of prolactin had no effect $(P>0.05$, Student's $t$ test $)$ on the organ weights, or on the hormonal serum or pituitary concentrations (Table 2).

Oestrogen-treated rats showed atrophic seminiferous tubules that were practically empty of germ cells (Fig. 1b). The testes of oestrogen plus gonadotrophin-treated rats showed complete spermatogenesis (Fig. 1c), being morphologically identical to those of control rats (Fig. la). The ventral prostate of oestrogen-treated rats showed small glandular acini with poorly developed lumina and most of the interglandular stroma was occupied by inflammatory cells (Fig. le) that in some areas infiltrated the epithelium and accumulated in the glandular lumen. Similar features were present in the ventral prostate of oestrogen plus gonadotrophin-treated rats (Fig. 1f). No detectable alterations were observed in any organ in prolactin-treated rats. 
Table 1. Effects of the administration of FSH and LH (Day 1 to Day 10) on organ weights and hormonal serum concentrations in control and oestrogenized (EB) rats

\begin{tabular}{|c|c|c|c|c|}
\hline & $\begin{array}{c}\text { Group } 1 \\
\text { (oil + vehicle) }\end{array}$ & $\begin{array}{c}\text { Group 2 } \\
\text { (EB + vehicle) }\end{array}$ & $\begin{array}{c}\text { Group 3 } \\
\text { (oil + FSH/LH) }\end{array}$ & $\begin{array}{c}\text { Group } 4 \\
(\mathrm{~EB}+\mathrm{FSH} / \mathrm{LH})\end{array}$ \\
\hline No. of animals & 8 & 12 & 10 & 10 \\
\hline \multicolumn{5}{|c|}{ Weight ( $\mathrm{mg} / 100 \mathrm{~g}$ body wt) of: } \\
\hline Testes & $944 \cdot 25 \pm 35 \cdot 01$ & $575 \cdot 16 \pm 57 \cdot 88^{a}$ & $1272 \cdot 73 \pm 38 \cdot 56^{\mathrm{a}}$ & $1116.97 \pm 58 \cdot 14^{\mathrm{a}, \mathrm{b}}$ \\
\hline Epididymides & $289.35 \pm 15.67$ & $154 \cdot 23 \pm 18 \cdot 93^{\mathrm{a}}$ & $149 \cdot 16 \pm 6 \cdot 68^{\mathrm{a}}$ & $256.09 \pm 18.98^{b, c}$ \\
\hline Seminal vesicles & $144.62 \pm 9.43$ & $43.40 \pm 8.93^{a}$ & $140 \cdot 12 \pm 7 \cdot 10$ & $69 \cdot 44 \pm 8.09^{\mathrm{a}, \mathrm{c}}$ \\
\hline Ventral prostate & $97.91 \pm 3.08$ & $32 \cdot 73 \pm 5 \cdot 27^{2}$ & $107 \cdot 10 \pm 7.56$ & $50.06 \pm 8 \cdot 73^{\mathrm{a} . \mathrm{c}}$ \\
\hline \multicolumn{5}{|c|}{ Concentrations $(\mathrm{ng} / \mathrm{ml})$ of: } \\
\hline Testosterone & $3.62 \pm 0.80$ & $0.67 \pm 0.15^{\mathrm{a}}$ & $2.67 \pm 0.43$ & $1.84 \pm 0.36$ \\
\hline LH & $1.06 \pm 0.14$ & $1.01 \pm 0.12$ & $1.08 \pm 0.14$ & $1 \cdot 10 \pm 0 \cdot 14$ \\
\hline FSH & $5.81 \pm 0.78$ & $6.68 \pm 0.50$ & $3.52 \pm 0.34^{\mathrm{a}}$ & $4.25 \pm 0.38^{a}$ \\
\hline Prolactin & $8.72 \pm 1.23$ & $14 \cdot 71 \pm 1 \cdot 20^{\mathrm{a}}$ & $6 \cdot 39 \pm 1 \cdot 30$ & $7 \cdot 10 \pm 0.98^{b}$ \\
\hline
\end{tabular}

Values are mean \pm s.e.m.

$P<0.05$ at least: a $v$ Group 1; b vs Group 2; c vs Group 3 (Anova followed by Tukey's test).

Table 2. Effects of the administration of prolactin (Day 1 to Day 10) on organ weights and hormonal serum and pituitary concentrations in rats $(12 /$ group $)$

\begin{tabular}{lrr}
\hline & \multicolumn{1}{c}{ Vehicle } & \multicolumn{1}{c}{ Prolactin } \\
\hline Testes (mg/100 g body wt) & $896.66 \pm 21.79$ & $932.58 \pm 20.59$ \\
Epididymides (mg/100 g body wt) & $273.58 \pm 13.04$ & $289.37 \pm 7.24$ \\
Seminal vesicles (mg/100 g body wt) & $146.28 \pm 15.31$ & $147.90 \pm 5.00$ \\
Ventral prostate (mg/100 g body wt) & $112.15 \pm 8.48$ & $119.17 \pm 9.57$ \\
Testosterone (ng/ml) & $3.34 \pm 0.60$ & $3.20 \pm 0.42$ \\
LH $(\mathrm{ng} / \mathrm{ml})$ & $1 \cdot 16 \pm 0.23$ & $1.20 \pm 0.10$ \\
FSH $(\mathrm{ng} / \mathrm{ml})$ & $6.38 \pm 0.40$ & $5.66 \pm 0.34$ \\
Prolactin $(\mathrm{ng} / \mathrm{ml})$ & $8.07 \pm 1.61$ & $5.57 \pm 1.27$ \\
LH $(\mu \mathrm{g} / \mathrm{mg} \mathrm{pituitary)}$ & $0.51 \pm 0.09$ & $0.58 \pm 0.04$ \\
FSH $(\mu \mathrm{g} / \mathrm{mg} \mathrm{pituitary)}$ & $0.38 \pm 0.12$ & $0.34 \pm 0.02$ \\
Prolactin $(\mu \mathrm{g} / \mathrm{mg}$ pituitary) & $0.29 \pm 0.04$ & $0.24 \pm 0.03$ \\
\hline
\end{tabular}

Values are mean \pm s.e.m.

\section{Discussion}

It is well known that neonatal oestrogen treatment causes permanent alterations in the hypothalamicpituitary-gonadal axis in male rats. Male rats treated with oestradiol on the first day of life showed low gonadotrophin and high prolactin concentrations, either in serum or hypophysis during the early post-natal period (Aguilar et al., 1987), suggesting that the effects of the neonatal oestrogen administration on the reproductive system might be indirect, as a consequence of the decrease in gonadotrophin and/or the increase in prolactin concentrations induced by oestrogens. In the present study, the direct and/or indirect effects of neonatal oestrogen treatment have been analysed.

The administration of FSH and LH from Day 1 to Day 10 abolished the effects of oestrogen on the testis, the testicular weight and serum testosterone concentrations being equivalent to those in control rats. This is also confirmed by the presence of complete spermatogenesis, which, in turn, implicates the morphological and functional integrity of Leydig and Sertoli cells. These results strongly suggest that the effects of oestradiol on testicular development are indirect, being mainly 

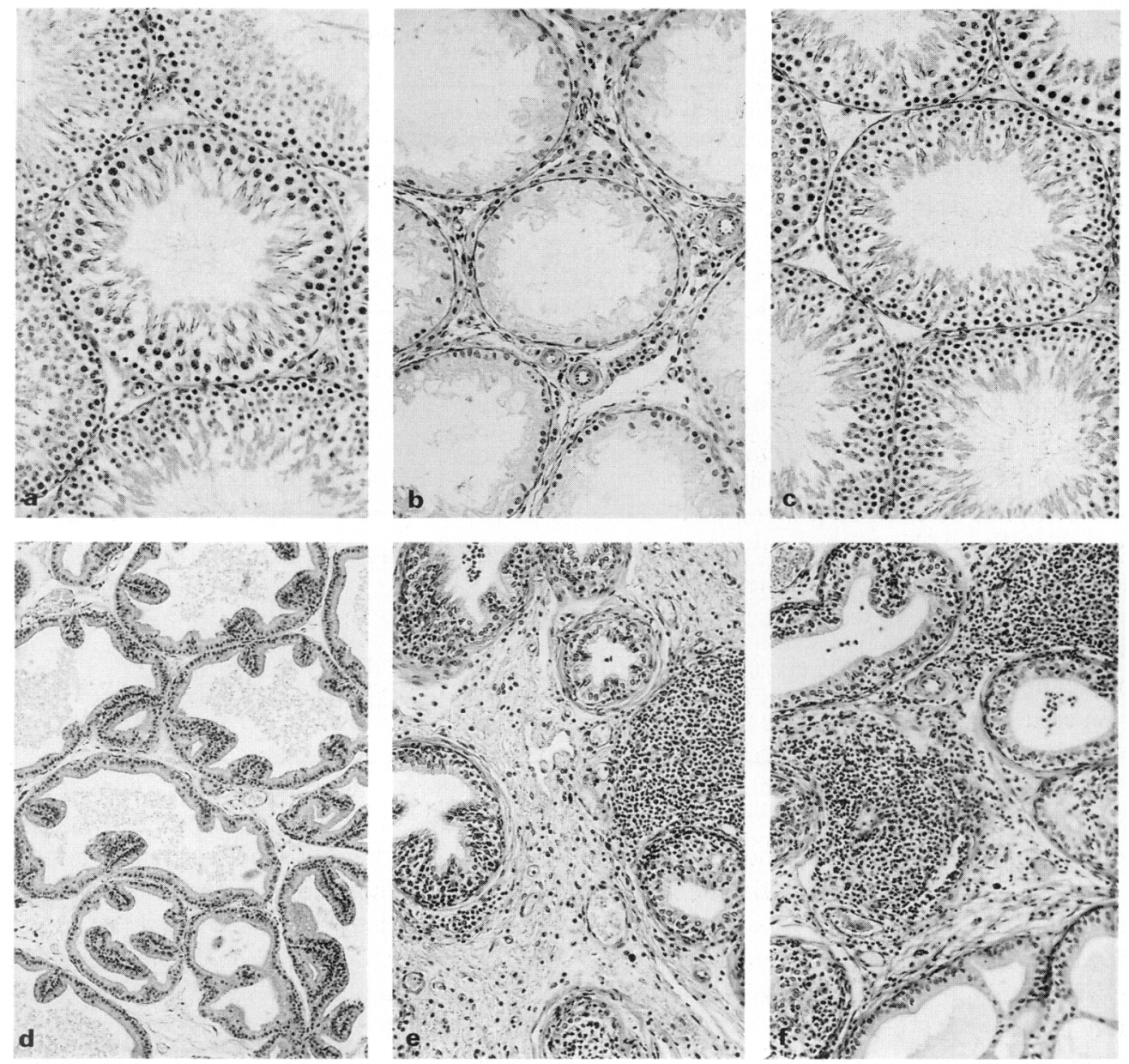

Fig. 1. Micrographs from the testis $(a, b, c)$ and ventral prostate $(d, e, f)$ from control $(a, d)$, oestrogen-treated $(b, e)$ and oestrogen + gonadotrophin treated $(c, f)$ rats. a,b,c,e,f $\times 100$; $\mathrm{d} \times 60$.

mediated by the central inhibition on gonadotrophin secretion. Cytosolic-nuclear oestrogen receptors are not present in the rat testis before 23 days of age (Abney \& Melner, 1979) and, at this age, the serum oestrogen concentrations are already normalized in neonatally oestrogen-treated rats (Bellido et al., 1985). Furthermore, related experimental schedules, such as treatment with GnRH antisera (Bercu et al., 1977; Bercu, 1982) or with a GnRH antagonist (Huhtaniemi et al., 1986; Kolho et al., 1988), that induced a transient decrease in plasma gonadotrophin concentrations also caused a permanent impairment of testicular functions although the effects were not completely equivalent to those obtained by oestrogen treatment. Plasma testosterone concentrations were normal after GnRH antiserum (Vogel et al., 1983), and increased after GnRH antagonists (Huhtaniemi et al., 1986) while they decreased after neonatal oestrogen treatment (present study). These differences may be related to the degree and/or duration of the gonadotrophin inhibition in different treatments. On the other hand, the post-natal gonadotrophin treatment did not prevent the establishment of permanent alterations in the sex accessory organs. It has been reported that neonatal oestrogen treatment permanently alters development and the androgen responsiveness of the sex accessory glands in adult life (Naslund \& Coffey, 1986), although the mechanism of steroid 
imprinting is not well established. The presence of a chronic inflammatory reaction in the ventral prostate is indicative of tissue damage. These results support the hypothesis that oestrogen has direct effects on the sex accessory glands. Adult animals treated neonatally with GnRH antagonists did not show atrophy of the sex accessory glands (Huhtaniemi et al., 1986; Kolho et al., 1988).

The role of prolactin in the male reproductive system is not clear, in spite of the numerous published data (Jones et al., 1983; Weaber et al., 1983; Smith et al., 1985; Cohen et al., 1988; Fung et al., 1989). The controversial data available in the literature seem to indicate that the actions of prolactin are closely related to the age of the animals and to the experimental approach used. The results of the present study showed that post-natal administration of prolactin did not affect the integrity of the reproductive system in adult life, despite the fact that we used doses higher than those previously reported (Chase \& Payne, 1985; Jones et al., 1983). Consequently, the alterations induced by neonatal oestrogen treatment seem to be independent of the increase in prolactin concentrations induced by oestrogens.

The normalization of prolactin serum concentrations and testicular function after post-natal gonadotrophin administration suggests that gonadotrophin post-natal concentrations could be important in the establishment of the mechanisms controlling prolactin synthesis, secretion and action on target organs. Post-natal treatment with $\mathrm{GnRH}$ antagonist increases prolactin pituitary content while it decreases prolactin testicular receptors (Huhtaniemi et al., 1986) and, in adult female rats, changes in FSH and LH secretion induced by LHRH antiserum induced long-term modifications in prolactin secretion (Kerdelhue et al., 1976). The decreased FSH (although not LH) serum concentrations in adult rats neonatally injected with gonadotrophins also suggested that the mechanisms controlling the secretion of the two gonadotrophins have been affected differently.

The antigonadotrophic effects of prolactin reported in adult animals (Tresguerres et al., 1981; Koike et al., 1984; Clayton, 1989) seem not to be present in neonatal rats, since prolactin administered exogenously does not change the development of the reproductive system, although the simultaneous study of prolactin and gonadotrophin serum concentrations during the post-natal period seems to be necessary to confirm this fact. The coexistence of decreased serum concentrations of testosterone with normal concentrations of LH and FSH in oestrogen-treated rats might indicate an increased set-point on the hypothalamic-pituitary axis to negative feedback regulation by testicular testosterone (Ojeda et al., 1980), similar to that described after treatment with GnRH antagonist (Huhtaniemi et al., 1986), as well as a diminished functional ability of Leydig cells.

In conclusion, this study provides evidence that the effects of oestradiol on testicular development are mainly indirect, as they are mediated by the central inhibition of gonadotrophin secretion, although oestradiol does act directly on the development of the sex accessory glands.

The National Pituitary agency supplied the radioimmunoassay materials for $\mathrm{FSH}$, $\mathrm{LH}$ and prolactin determinations. We thank Mrs Teresa Recio for her invaluable technical help and Mrs Inés Molina for typing the manuscript. This work was supported by a grant from CAICYT (PB86-004).

\section{References}

Abney, T.O. \& Melner, M.H. (1979) Characterization of estrogen binding the developing rat testis. Ontogeny of the cytoplasmic estrogen receptor. Steroids $\mathbf{3 4}$, 413-427.

Aguilar, E., Tejero, A., Vaticón, M.D. \& Fernandez Galaz, C. (1984) Dissociation of luteinizing hormone and follicle-stimulating hormone control mechanisms in male and female rats by neonatal administration of estradiol benzoate or testosterone propionate. Hormone Res. 19, 106-116.
Aguilar, E., Bellido, C., Aguilar, R., Pinilla, L., Tejero, A. \& Fernández Galaz, C. (1987) Mechanisms in the production of prepuberal reproductive defects in neonatal estrogenized male rats. Andrologia 19, 22-31

Bellido, C., Gaytán, F., Aguilar, R., Pinilla, L. \& Aguilar, E. (1985) Prepuberal reproductive defects in neonatal estrogenized male rats. Biol. Reprod. 33, 381-387.

Bercu, B.B. (1982) Neutralization of gonadotropinreleasing hormone in neonatal rats with permanent Downloaded from Bioscientifica.com at $04 / 26 / 2023$ 02:47:18AM via free access 
impairment of the hypothalamic-pituitary-testicular axis. Biol. Reprod. 26, 612-619.

Bercu, B.B., Jackson, I.M.D., Sawin, C.T., Safaii, H. \& Reichlin, S. (1977) Permanent impairment of testicular development after transient immunological blockade of endogenous luteinizing releasing hormone in the neonatal rat. Endocrinology 101, 1871-1879.

Chase, D.J. \& Payne, A.H. (1985) Prolactin involvement in regulation of testicular $5 \alpha$-reductase activity in the immature rat. Biol. Reprod. 33, 637-643.

Clayton, R.N. (1989) Gonadotropin-releasing hormone: its actions and receptors. J. Endocr. 120, 11-19.

Cohen, H., Guillaumot, P.\& Sabbach, I. (1988) Dissociated estradiol $E_{2}$ action on the pituitary-testicular axis in a genetically hyperprolactinemic rat (IPL nude rat). $J$. Steroid Biochem. 30, 407-410.

Dhar, J.D. \& Setty, B.S. (1976) Epididimal response to exogenous testosterone in rats sterilized neonatally by estrogen. Endokrinologie 68, 14-41.

Frick, J., Chang, C.C. \& Kincl, F.A. (1969) Testosterone plasma levels in adult male rats injected neonatally with estradiol benzoate or testosterone propionate. Steroids 13, 21-27

Fung, M-Ch., Wah, G. \& Odell, W.D. (1989) Effects of prolactin on luteinizing hormone-stimulated testosterone secretion in isolated perfused rat testis. $J$. Androl. 10, 37-42.

Gay, V.L. \& Kerlan, J.T. (1978) Serum LH and FSH following passive immunization against circulating testosterone in intact male rat and orchidectomized rats bearing subcutaneous silastic implants of testosterone. Archs Androl. 1, 257-266.

Gaytan, F. \& Aguilar, E. (1986) Quantitative analysis of Sertoli cells in neonatally oestrogen-treated rats. $J$. Reprod. Fert. 79, 589-598.

Gaytán, F., Lucena, M.C., Pinilla, L. \& Paniagua, R. (1986a) Effects of neonatal estrogenization on germ cell development. Z. mikrosk. Anat. Forsch. 100, 290-300.

Gaytán, F., Pinilla, L., Aguilar, R., Lucena, M.C. \& Paniagua, R. (1986b) Effects of neonatal estrogen administration on the rat testis development with particular reference to Sertoli cells. J. Androl. 7, $112-121$.

Greenwood, F.C., Hunter, W.M. \& Glover, J.S. (1963) The preparation of ${ }^{131}$ I-labelled human growth hormone of high specific radioactivity. Biochem. J. 89, $114-123$.

Haggi, E. \& Aoki, A. (1981) Prolactin content in rat pituitary gland. RIA of prolactin after different extraction procedures. Acta endocr., Copenh. 97, 338-342.

Huhtaniemi, I.T., Nevo, N., Amsterdan, A. \& Naor, Z. (1986) Effects of postnatal treatment with a gonadotropin-releasing hormone antagonist on sexual maturation of male rats. Biol. Reprod. 35, 501-507.

Jones, R., Rising, P.R. \& Parker, M.G. (1983) Effects of prolactin on testosterone-induced growth and protein synthesis in rat accessory sex glands. $J$. Endocr. 96, 407-416.

Kerdelhue, B., Catin, S., Kordon, C. \& Justisz, M. (1976) Delayed effects on in vivo LHRH immunoneutralization on gonadotropins and prolactin secretion in female rats. Endocrinology 98, 1539-1549.
Kincl, F.A., Folch, P.A., Maqued, M., Herrera Laso, L., Oriol, A. \& Dorfman, R.I. (1965) Inhibition of sexual development in male and female rats treated with various steroids at the age of five days. Acta endocr., Copenh. 49, 193-206.

Koike, K., Aono, T., Kiyake, A., Tasaka, K., Chatani, F. \& Kurachi, K. (1984) Effects of pituitary transplant on the LH-RH concentrations in the medial basal hypothalamus and hypophyseal portal blood. Brain Res. 301, 253-258.

Kolho, K-L., Nikula, H. \& Huhtaniemi, I. (1988) Sexual maturation of male rats treated postnatally with a gonadotropin-releasing hormone antagonist. $J$. Endocr. 116, 241-246.

Naslund, M.J. \& Coffey, D.S. (1986) The differential effects of neonatal androgen, estrogen and progesterone on adult rat prostate growth. J. Urol. 136, 1136-1140.

Ojeda, S.R., Andrews, W.W., Advis, J.P. \& Smith White, S. (1980) Recent advances in the endocrinology of puberty. Endocr. Rev. 1, 228-257.

Pinilla, L., Aguilar, R., Bellido, C. \& Aguilar, E. (1985) $\mathrm{LH}$ response to $\mathrm{LH}-\mathrm{RH}$ neonatally estrogenized male rats. Andrologia 17, 254-256.

Pinilla, L., Cocconi, M., Zoppi, S. \& Martini, L. (1989) Effect of neonatal estrogenization on testosterone metabolism in the prostate and in the epididymis of the rat. J. Steroid Biochem. 32, 459-465.

Rodríguez Padilla, M., Bellido, C., Pinilla, L. \& Aguilar, E. (1987) Secretion of LH in spontaneously hypertensive rats. $J$. Endocr. 113, 255-260.

Smith, C., Assimos, D., Lee, Ch. \& Grayhack, J.T. (1985) Metabolic action of prolactin in regressing prostate: Independent of androgen action. The Prostate 6, 49-59.

Steinberger, E., Chrowdhury, M. \& Tcholakian, R. (1977) Effect of estradiol benzoate on the pituitary-gonadal axis of the intact male rat. Andrologia 9, 307-312.

Tresguerres, J.A.F., Esquifino, A.I., Pérez Méndez, L.F. \& López Calderón, A. (1981) Possible role of prolactin in the inhibitory effect of estradiol on the hypothalamic-pituitary-testicular axis in the rat. Endocrinology 198, 83-87.

van Beurden, W.M.O., Roodnat, B., Mulder, E. \& van der Molen, H. (1978) Further characterization of the effects of hypophysectomy, FSH and estrogen on LH stimulation of testosterone production in Leydig cells from immature rats. Steroids 31, 83-98.

Vaticón, M.D., Fernández Galaz, M.C., Tejero, A. \& Aguilar, E. (1985) Alteration of prolactin control in adult rats treated neonatally with sex steroids. $J$. Endocr. 195, 429 433 .

Vogel, D.I., Gunsalus, G.L., Bercu, B.B., Musto, N.A. \& Bardin, C.W. (1983) Sertoli cell maturation is impaired by neonatal passive immunization with antiserum to luteinizing hormone-releasing hormone. Endocrinology 112, 1115-1121.

Weaber, C., Reymond, M. \& Lemarchand-Beraud, T. (1983) Effects of hyper- and hypoprolactinemia on gonadotropin secretion, rat testicular luteinizing hormone/human chorionic gonadotropin receptors and testosterone production by isolated Leydig cells. Biol. Reprod. 28, 167-177. 